\title{
The Integration of Socialist Core Values with College English Teaching under the Concept of "Ideological and Political Theory Teaching in All Courses"
}

\author{
Feipeng Li, Chen Guan \\ College of Foreign Languages Education and International Business, Baoding University, Baoding, China \\ Email: lfp19801104@163.com
}

How to cite this paper: Li, F. P., \& Guan, C. (2020). The Integration of Socialist Core Values with College English Teaching under the Concept of "Ideological and Political Theory Teaching in All Courses". Creative Education, 11, 2416-2423. https://doi.org/10.4236/ce.2020.1111177

Received: October 29, 2020

Accepted: November 23, 2020

Published: November 26, 2020

Copyright $\odot 2020$ by author(s) and Scientific Research Publishing Inc. This work is licensed under the Creative Commons Attribution International License (CC BY 4.0).

http://creativecommons.org/licenses/by/4.0/

\section{(c) (i) Open Access}

\begin{abstract}
The eighteenth National Congress of the CPC clearly put forward cultivation and practicing socialist core values which are the concentrated expression of spirits of China in modern times. With distinctive traits of instrumentalism and humanism, college English serves as a significant platform for socialist core values education for students. Based on the idea of ideological and political teaching in all courses and with the objective of fostering talents with political integrity and professional competence, this paper firstly introduces the basic concept of socialist core values and the importance of ideological and political education in universities. Then it analyzes the significance and necessities of integrating socialist core values education into college English course. In the fourth part, the paper deeply probes valid strategies to achieve the educational idea of "from course of ideological and political teaching to courses for ideological and political teaching" in college English teaching and learning from the perspectives of teachers' improvement, scientific utilization and excavation of textbooks and innovation of teaching approaches and models. Finally, conclusions and reflections that need close attention are listed and discussed in the last part of this paper.
\end{abstract}

\section{Keywords}

Socialist Core Values, College English, Necessities, Awareness, Textbooks, Teaching Approaches

\section{Introduction}

General Secretary Xi Jinping stressed at the National Conference on Ideological and Political Work in Colleges and Universities that we should adhere to foster- 
ing virtue through education as the central link, implement ideological and political work throughout the whole process of teaching, and realize the whole process of education and all-round education. The eighteenth National Congress of the CPC clearly put forward the socialist core values that can be summed up as prosperity, democracy, civility, harmony, freedom, equality, justice, the rule of law, patriotism, dedication, integrity, and friendship. The nineteenth National Congress of the CPC stressed that socialist core values should be integrated into every aspect of social development, and transformed into emotional identification and behavioral habits. The cultivation of socialist core values is an important component of ideological and political education and should be incorporated into the overall plan of national education.

As one of the basic compulsory courses for general education, college English class takes up more hours than other courses and has broader student coverage. Under the idea of ideological and political theory teaching in all courses, college English teachers not only need to improve students' English knowledge and skills, but also shoulder the responsibility of cultivating political accomplishment and ethical standards of students, which sets a higher demand on the quality and ability of college English teachers. The teaching and cultivating objectives of college English teaching are required to comply with the principles of ideological and political teaching especially the socialist core values. College English has the quality of instrumentalism and humanism. Embedding socialist core values in college English teaching is an urgent need for national culture construction, for the improvement of ideological and political work, and for the building of a community with shared future for mankind. According to the finding of a survey conducted by the research group led by the author, only $39 \%$ English teachers listed ideological and political education in their lesson planning, 59\% English teachers acknowledged that they had the awareness of putting ideological and political elements into their teaching, $96 \%$ teachers have never conducted evaluation concerning socialist core values in English class. For the purpose of developing steadfast believers, active communicators and exemplary practitioners of socialist core values, this paper will probe into a range of efficient strategies on integrating socialist core values cultivation into college English class from perspectives of teachers' development, teaching materials' excavation and adjustment, teaching approaches and models, and valid assessment of teaching.

\section{Literature Review}

The Construction Guidelines of Ideological and Political Education in All Courses of Universities and Colleges was issued by Education Ministry of China on June $1^{\text {st }}, 2020$. Guidelines for Strengthening and Improving Universities Propaganda and Ideological Work under New Situation of Views stresses that we should integrate socialist core values into the whole process of higher education and give full play to the educational function of university philosophy and social sciences. College English Curriculum Requirements points out that the socialist core values should be organically incorporated into college English 
teaching contents. With increasing emphasis on ideological and political education in all courses, more and more teachers and scholars hsave carried out correlational studies from different perspectives and a series of productive results have been achieved from a strategic version

Yang Xiyan (2016a) analyzed the significance of integrating core values of socialism into English class from the strategic importance of talent cultivation. Zhao Lan (2016) argued that cultivating and practicing socialist core values in college English teaching is the requirement for improving of quality of talent cultivation. College English course should not only emphasize English language teaching and help students to grasp language ability of international communication, but also should attach great importance to the cultivation and practice of socialist core values through language teaching. Zhao Yanfang (2017) and Wang Shujing (2017) explored effective paths of implementing core values of socialism cultivation in college English class from the angle of implicit education. They held that implicit education should be a process of "step by step" and perseverance so as to consolidate and promote the efficiency of penetrative education. Lian Wenwen (2020) carried out investigations of new media construction including official Wechat, official micro blog and new media platform of seventy-two universities and colleges, then expounded six efficient approaches to pushing socialist core values education for college students through new media. He found through research that the fast development of new media is bringing significant influence on college students' learning, life, psychology and values, and playing a role that couldn't be ignored in carrying out socialist core values education of college students. His findings and suggestions provide important enlightenment and reference for this research.

\section{Significance and Necessities of Integrating Socialist Core Values into College English Teaching}

As the eternal exchange of economy and culture increasingly deepening, the impact of western cultures on China is becoming wider and wider. Chinese culture and mainstream values have always been ignored in English teaching for a long time, thus causing the current situation that students learn a lot about western cultures but don't know well about native cultures and values, let alone to use English to introduce Chinese cultures and tell China stories to westerners. Therefore, it becomes urgent and necessary to integrate core values of socialism into college English class.

\subsection{An Urgent Need for the Construction of Native Culture}

Under the background of economic globalization and ideological diversification of the world, there have been increasingly frequent and deep communications of ideology and culture among countries, and the competition in the field of culture has become a major concern for most of countries. Values are the spiritual backbone and essence of culture, and the competition of cultures is actually the competition of values (Zhou, 2008). Any country that wants to establish its cul- 
tural status and preserve its cultural traditions must dig into and develop its core values (Yang, 2016b). Language is the carrier of culture. It is inevitable for students to feel confused about choices of values when encountering the impact of different ideology, cultures and values from western countries in the process of English language learning. Successful intercultural communication is to actively spread national culture based on learning about and respect foreign cultures.

\subsection{An Urgent Need for Strengthening and Improving College Students Ideological and Political Work}

It is of great importance to mould correct political belief, ideal faith and moral sense of college students because they will produce enormous influence on the development of socialism with Chinese characteristics. The cultivation of socialist core values is essential content and vital task of the ideological and political education for college students. Ideological and political theory course is the main channel for university to implement socialist core values education of students. However, there exist several problems such as unitary teaching model, laggard educational idea and unsatisfactory teaching efficiency. Socialist core values education should not only depend on traditional ideological and political theory course, but also fully excavate the function of socialist core values education "hidden" in all the other courses. Targeted integration of socialist core values education base on teaching contents is the extension and supplement of ideological and political course.

\subsection{A Need for Exploiting the Advantage of College English Course and Enriching Its Connotation}

Language is inseparable from culture. English teaching not only refers to the instruction of English knowledge and language skills, but also includes the introduction and interpretation of ideology and cultures of western society. Inter-cultural communication should be "two-way". The socialist core values which absorb the essence of traditional culture of China are the creative transformation and innovative development of traditional Chinese culture with epochal character and inclusiveness. In the communication and confrontation with western cultures, college English teachers can targetedly introduce the topics concerning national ideals, social regulations and civic virtues. Students will be more likely to appreciate national cultures and socialist core values through the comparison between Chinese and western cultures. New age gives new meaning to college English course. Carrying out socialist core values education in college English class can realize the sublimation of teaching materials related to nation, society and individual thus enriching and deepening teaching contents.

\section{Strategies of Integrating Socialist Core Values into College English Course}

\subsection{Improving Teachers' Qualities and Ideological Awareness}

Embedding socialist core values in college English class calls for continuously 
improving English teachers' comprehensive qualities and moral characters and actively instructing students to set up correct values and adhere to the guiding status of socialist core values. According to the questionnaire survey, nearly $65 \%$ teachers weren't well acquainted with the contents of ideological and political theory, even couldn't clearly express the complete contents of socialist core values. Firstly, teachers are advised to infect students with sturdy ideal and beliefs, affect students through daily teaching and instructing work, and facilitate the formation of students' socialist core values, because teachers' words and deeds have imperceptible influence on students. It is of great significance for teachers to constantly enhance their own moral cultivation and cultural attainment in order to subtly infect students. Strengthening socialist core values education in college English teaching demands that teachers should fully recognize socialist core values, work hard to develop their own political accomplishment, build firm socialist ideal and belief, consciously resist invasion of unhealthy thoughts, and dedicate themselves to practicing socialist core values. It is particularly crucial for English teachers because of the feature of their major. Secondly, it is necessary to cultivate teachers' consciousness and ability of socialist core values education. It is required that college English teachers attach great significance to cultivating students' values and beliefs, embed socialist core values in English teaching contents, and adopt various teaching approaches in order to enable students to make dialectical comparison between Chinese and western values and concepts in the process of English learning. Therefore, universities and colleges are supposed to emphasize the work of cultivating teachers' teaching ability and moral qualities, pass correct values and ideas to students, thus enabling them to set up core values of socialism.

\subsection{Scientifically Utilizing and Deeply Excavating Textbooks}

One of the keys to implementing socialist core values education in college English class lies in finding out the point of penetration from teaching contents for the integration of the core values of socialism so that the objectives and principles of the three levels of nation, society and individual reflected from socialist core values can be realized and practiced. Covering expansive and diverse fields, the contents of college English have wide and close connection with the connotation of socialist core values.

A majority of college English books derive from original edition of western countries usually with a distinctive theme of each unit. Based on the cultural background knowledge contained in the articles, teachers are suggested to cannily excavate value ideas behind cultural phenomena so as to realize the socialist core values education of students. With the principle of "moderation" and "flexibility", teachers can pertinently guide students to take in socialist core values instead of "preaching". For example, when teaching the unit with the topic of nation, society or the world such as race, environment, peace, responsibility, teachers could consciously incorporate the socialist core values of "patriotism, democracy, civilization, harmony, freedom and justice" into class. 
Teachers also can combine abstract contents of socialist core values with society and actively inspire students to keep a watchful eye on social hot spots and politics of current events, thus enriching the contents of English teaching and socialist core values education, guiding students to ponder over social phenomena and express their thought about those in English.

\subsection{Enriching and Innovating Teaching Approaches and Means}

Firstly, implement recessive education. According to the questionnaire survey, $63 \%$ teachers didn't have efficient ways to implement socialist core values in English class, $55 \%$ of which felt that it was very hard to handle the balance between English language teaching and moral education. Maybe Teachers could try to actively create scenes for students' learning. The construction of relaxing learning atmosphere can stimulate students' learning interest and subjective initiative. For example, when it comes to the topic of patriotism, teachers can heighten the classroom atmosphere by reading article or telling moving story with full emotion or playing the video of dress parade. It may contribute to making students open up their emotional world, realize the interaction between subject and object and acquire emotional experiences. Students' emotion of patriotism can be stimulated and their language ability and humanistic qualities will be synchronously promoted. Besides, it is advisable for teachers to duly design and organize class discussion. For example, if the unit theme is "integrity", teachers may guide students to list out some cases concerning integrity. Through discussion, students are likely to gather various problems that can be seen at times such as class cut, cheating in exams, plagiarism. The way of "education and self-education" is helpful in deepening students' understanding about the problems that need to be reflected on and resolved.

Secondly, fully utilize the second class activities and network resources. It may be a good idea for teachers to assign tasks which are related to socialist core values to students in the link of extracurricular practice. Then students will be required to give their presentation in class and teachers offer their feedback. The forms of presentations and activities can be scene play, speech, storytelling, debate, role play, news broadcast and so on. With the fast development of internet and We-media, it is necessary and urgent for teachers to make full use of modern teaching technology. Teachers are required to realize the combination of English teaching and socialist core values by means of multi-media teaching facilities and online teaching platform. For instance, teachers are encouraged to make use of school public platform and Wechat Official Account to push English visions of socialist core values in order to give students positive guide to establish correct values and political beliefs.

\section{Conclusion}

The implementation of ideological and political education in all courses has become crucial requirements of the new era. The cultivation of the socialist core 
values is a significant component of ideological education. College English teachers are required to shoulder the mission of education and cultivation as well as the responsibility to impart language knowledge and skills. College English class with the education of socialist core values will create good atmosphere for all-rounded cultivation and enrich the connotation of college English course.

A variety of teaching strategies can be adopted to achieve socialist core values education during the process of college English teaching. From the angle of English teachers, they are required to overcome the disturbances from foreign cultures and improve their own moral qualities and values. The training of socialist core values and new media technologies for English teachers should also be emphasized. Another point that requires close attention is that the education of socialist core values in English while, teacher class needs to be carried out based on teaching materials and contents. Means are suggested to flexibly combine the elements of socialist core values with textbooks. With all these methods students will not only develop their language knowledge and skills but also cultivate correct sense of values.

Meanwhile, some problems need special attention in the implementation of socialist core values education in college English class. For example, there exists much negative information even ultra-reactionary ideas in the internet resources which may produce negative influences on students. Therefore, it is required that college teachers play a role of "conductor" who rationally utilizes network materials and makes internet a powerful tool to help students build correct sense of values.

\section{Funding}

The thesis is the research result of Social Science Development Research Project of Hebei Province: The Ways of Integrating Ideological and Political Education in College English Teaching, project number: 201703050201.

\section{Conflicts of Interest}

The authors declare no conflicts of interest regarding the publication of this paper.

\section{References}

Lian, W. W. (2020). New Media Approach to Pushing Core Values of Socialism Education for College Students. Beijing Education, No. 10, 47-49.

Wang, S. J. (2017). Exploration of Implicit Education of Core Values of Socialism in College English Teaching. Journal of Inner Mongolia Normal University, No. 11, 130-133.

Yang, H. Y. (2016a). Moral and Cultural Consciousness and the Cultivation of Socialist Core Values. Academic Forum, No. 4, 97-99.

Yang, X. Y. (2016b). The Strategic Significance and Focus of Integrating Core Values of Socialism into English Talent Cultivation. Leading Journal of Ideological and Theoretical Education, No. 4, 95-98.

Zhao, L. (2016). Cultivating and Practicing the Core Values of Socialism in English 
Teaching. China Higher Education, No. 17, 39-40.

Zhao, Y. F. (2017). The Implicit Cultivation of Socialist Core Values in College English teaching. Science and Technology Vision, No. 28, 16-17.

Zhou, H. B. (2008). Socialist Core Values Education for College Students under Multi-Cultural Background. Heilongjiang Researches on Higher Education, No. 8, 104-106. 